\title{
STUDI KELAYAKAN PEMBANGUNAN MALL BARU DI KOTA HARAPAN INDAH
}

\author{
Raul Acacia ${ }^{1)}$, Liong Ju Tjung ${ }^{2)}$, Sylvie Wirawati ${ }^{3)}$ \\ 1)Program Studi S1 PWK, Fakultas Teknik, Universitas Tarumanagara, raulacacia@gmail.com \\ 2) Program Studi S1 PWK, Fakultas Teknik, Universitas Tarumanagara, liongjutjung@gmail.com \\ ${ }^{3)}$ Program Studi S1 PWK, Fakultas Teknik, Universitas Tarumanagara, sylvie.wirawati@gmail.com
}

Masuk: 10-08-2020, revisi: 07-09-2020, diterima untuk diterbitkan: 25-09-2020

\begin{abstract}
Abstrak
Pertumbuhan properti yang terus meningkat secara signifikan di Indonesia, terutama berpusat pada kota Jakarta menyebabkan kota-kota satelit seperti Kabupaten Bekasi menjadi salah satu pilihan dalam pengembangan properti, Damai Putra Group selaku salah satu pengembang yang besar membuat kota baru yang letaknya berbatasan dengan Jakarta, tepatnya Jakarta Timur. Dengan aksesibilitas yang baik dan saat ini pula sudah ada transportasi umum maka akan semakin meningkatkan aktifitas dan nilai lahan di Kota Harapan Indah. Damai Putra Group melihat ini sebagai peluang, dengan sudah mulai cukup padatnya kepadatan penduduk di Kota Harapan Indah ingin menyediakan fasilitas komersial pendukung yaitu membangun mall baru di Kota Harapan Indah. Studi kelayakan ini memiliki tujuan utama untuk meminimalisir resiko dan juga untuk mengetahui potensi dan ancaman yang ada, serta bertujuan untuk mengetahui kelayakan pembangunan secara finansial, dan juga menghasilkan konsep mall sesuai dengan tren dan kondisi pasar saat ini. Dalam hal ini penulis menggunakan beberapa cara untuk mengumpulkan data dengan pengumpulan primer maupun sekunder, yaitu survei lapangan, wawancara, dan dokumentasi. Penulis melakukan beberapa analisis untuk mencapai tujuan itu berupa analisis lokasi dan tapak, analisis pasar, analisis konsep pengembangan, dan analisis investasi. Hasil dari studi kelayakan ini berdasarkan analisis yang telah dilakukan menunjukan bahwa lahan ini layak untuk dikembangkan menjadi mall.
\end{abstract}

Kata Kunci : Pusat Perbelanjaan; Investasi; Studi Kelayakan

\begin{abstract}
The growth of property continues to increase significantly in Indonesia, especially centered on the Jakarta causing satellite cities such as Bekasi Regency to be one of the options in property Development. Damai Putra Group as one of the developers to create a new township that is directly adjacent with Jakarta, especially East Jakarta. With good accessibility and now there is also public transport, it will increase the activity and value of land in Kota Harapan IndahDamai Putra Group sees this as an opportunity, with a number that has begun to be quite densely populated in Kota Harapan Indah wanting to provide supporting facilities to build new mall in Kota Harapan Indah. This feasibility study aims to determine the potential and threats that exist and also minimize risks, and studying the feasibility especially in financial, and also produce the concept of mall in accordance with current market trends and conditions. In this case, the author uses several methods to collect data with primary and secondary data collection, namely field surveys, interviews, and documentation. In this case the authors conducted several analyzes to achieve the objectives consisting of location and site analysis, market analysis, development concept analysis, and investment analysis. The results of this feasibility study based on the analysis that has been done show that this land is eligible to be developed into a mall.
\end{abstract}

Keywords : Shopping Mall; Investment; Feasibility Study 


\section{PENDAHULUAN}

\section{Latar Belakang}

Kota Harapan indah yang mulai dikembangkan pada tahun 1987 pada saat ini, sudah ada kurang lebih 25.000 kepala keluarga yang sudah tinggal di Kota Harapan Indah, tentunya dibutuhkan fasilitas penunjang untuk memenuhi kebutuhan sehari hari masyarakat urban yang tinggal di Kota Harapan Indah. Dengan luas lahan sebesar 2.200 hektar, dan baru 700 hektar yang dibangun oleh Damai Putra Group, jadi masih sekitar 1500 hektar lagi yang akan dibangun sebagai perluasan dari Kota Harapan Indah. Luas lahan mall itu sendiri seluas $59.092 \mathrm{~m}^{2}$, posisinya di distrik dua, CBD Kota Harapan Indah. Dalam mendukung perkembangan Kota Harapan Indah sebagai Kota Baru banyak fasilitas pendukung yang dibutuhkan seperti Hotel, Mall, Apartemen, dan sebagainya. Kota Harapan Indah yang letaknya strategis dan mudahnya aksesibilitas ke lokasi menjanjikan sebagai kota satelit yang ikut membantu perkembangan bisnis dan perdagangan di wilayah Bekasi Studi kelayakan investasi ini dilakukan untuk memperhitungkan resiko yang ada, mengingat modal yang akan dikeluarkan juga tidak sedikit, sedangkan manfaatnya baru akan bisa dirasakan di masa mendatang, dimana resiko itu akan selalu ada, untuk paling tidak mempertimbangkan dan meminimalisir resiko yang ada, dan juga menghitung keuntungan yang bisa diperoleh makan studi kelayakan ini perlu dilakukan.

\section{Rumusan Masalah}

a. Luas lahan seluas $59.092 \mathrm{~m}^{2}$ dengan harga yang cukup tinggi membuat PT Hasana Damai Putra untuk ingin mengetahui kelayakan pembangunan mall di Kota Harapan Indah.

b. Permintaan properti yang terus meningkat, khususnya di kota Jakarta yang memiliki keterbatasan lahan dan meningkatnya nilai lahan, sehingga pembangunan dilakukan di Kabupaten Bekasi yang mana lebih menguntungkan dari sisi ekonomi.

\section{Tujuan}

a. Mengetahui kelayakan secara finansial dari lahan yang akan dikembangkan.

b. Menghasilkan konsep yang dikembangkan sesuai dengan tren dan kondisi pasar.

c. Mengetahui profil, karakteristik, potensi, dan masalah dari lahan yang akan dikembangkan.

\section{KAJIAN LITERATUR}

Yang dimaksud dengan studi kelayakan proyek menurut (Yuliati, 2014) adalah studi tentang bisa tidaknya suatu proyek (biasanya merupakan proyek investasi) dilaksanakan dengan berhasil/meraih keuntungan.

Investasi adalah penanaman modal (baik modal tetap maupun modal tidak tetap) yang digunakan dalam proses produksi untuk memperoleh keuntungan suatu perusahaan. Investasi penting bagi kelanggengan masa depan perusahaan, tetapi juga merupakan topik yang secara konseptual sulit dan komplek (Sumastuti, 2006)

Pengembangan menurut (Multiyaningsih, 2008) memiliki artian sebagai sebuah penelitian yang digunakan untuk mengembangkan dan mevalidasi suatu produk.

Menurut (Kyle, 2002) membedakan tingkatan properti mulai dari tanah dan sumbar daya alam yang melekat (Land), segala pengembangan buatan manusia yang ada dan melekat pada Tanah (Real Estate) serta adanya hak kepemilikan atas tanah beserta semua pengembangannya yang dilindungi oleh hukum yang berlaku

Shopping mall merupakan pusat perbelanjaan yang berisikan satu dan beberapa department store besar sebagai daya tarik retail-retail kecil dan rumah makan dengan tipologi bangunan seperti toko yang menghadap ke koridor utama mall atau pedestrian yang merupakan unsur 
utama dari sebuah shopping mall dengan fungsi sebagai sirkulasi dan sebagai ruang komunal bagi terselenggaranya interaksi antar pengunjung dan pedagang (Maitland, 1987).

Menurut (Rangkuti, 2010) Analisis SWOT adalah indikasi berbagai faktor secara sistematis untuk merumuskan strategi perusahan. Analisis ini dilakukan untuk dapat mengoptimalkan kekuatan (strenght) dan peluang (opportunities), namun secara bersamaan dapat meminimalkan kelemahan ( weaknesses) dan ancaman (threats).

Menurut (Camp, 2006) Benchmarking adalah proses pengukuran yang menerus menyangkut produk, jasa dan praktek-praktek perusahaan terhadap kompetitor terbaik, suatu proses pengukuran terus menerus atas suatu produk jasa dan tata cara kita terhadap pesaing kita yang terkuat atau badan usaha lain yang dikenal sebagai yang terbaik.

Menurut (Griffin, 2006) segmentasi merupakan proses membagi pasar keseluruhan suatu produk atau jasa kedalam beberapa segmen yang memiliki kesamaan dalam hal minat, daya beli, geografi, perilaku pembelian maupun gaya hidup.

Dalam mengevaluasi segmen pasar yang berbeda perusahaan harus melihat dua faktor yaitu daya tarik pasar secara keseluruhan serta tujuan dan resource perusahaan (Kotler, 2003)

Dalam metode discounted cash flow, nilai dari suatu asset merupakan present value dari expected cash flow asset tersebut yang kemudian didiskontokan (discounted back) pada suatu nilai discount rate yang menggambarkan tingkat risiko dari expected cash flow tersebut (Damodaran, 2006).

\section{METODE}

Dari semua data yang ada, ada yang diperoleh secara pengamatan langsung pada lahan, survey lapangan, wawancara, dokumentasi, dan lain lain. Lalu ada juga data yang diperoleh melalui media informasi, dan juga data yang diperoleh dari PT Hasana Damai Putra selaku pemilik lahan objek studi, Berikut adalah cara pengumpulan datanya .

a. Survey lapangan

Survey lapangan dapat dilakukan dengan mengamati secara langsung objek studi tersebut. Melalui metode ini, peneliti dapat memahami kondisi eksisting objek studi. Dalam studi ini, survey lapangan dilakukan langsung kepada objek lahan pengembangan, sehingga didapatkan data mengenai :

- Letak dan batas-batas lahan dengan dibantu dengan data sekunder dari google maps

- Kondisi dan penggunaan lahan eksisting di sekitar lahan dengan dibantu dengan data sekunder dari google maps

- Aksesibilitas menuju lahan dengan dibantu dengan data sekunder dari google maps

- Fasilitas sekitar yang tersedia di sekitar lahan dengan dibantu dengan data sekunder dari google maps

- Status tanah dan kepemilikan, lahan dengan informasi dari PT Hasana Damai Putra

- Intensitas bangunan dari lahan dengan informasi dari PT Hasana Damai Putra

- Visual dari lahan

- Aktivitas lingkungan di sekitar lahan

b. Wawancara

Wawancara dilakukan untuk memperdalam data ynag sudah didapatkan melalui survey lapangan. Dalam metode ini, penulis harus menyiapkan daftar pertanyaan utnuk memperoleh data-data yang diperlukan. Wawancara dilakukan dengan tim marketing dari PT 
Hasana Damai Putra dikarenakan tim perencanaan tidak bersedia, dan juga dikarenakan dengan kondisi sekarang ini yang sedang dilanda virus COVID-19.

c. Dokumentasi

Dokumentasi dilakukan untuk menunjang data-data lainya. Ini dilakukan dengan mengdokumentasikan dalam bentuk data visual seperti foto. Hasil dokumentasi tersebut dapat digunakan untuk menggambarkan kondisi eksisting dari objek studi secara visual.

Pada penelitian ini dilakukan dokumentasi meliputi :

- Kondisi didalam dan diluar lahan pengembangan

- Kondisi sekitar lahan pengembangan dengan radius $3 \mathrm{~km}$

- Aksesibilitas ke objek studi

d. Penyebaran Kuisioner

Penyebaran kuisioner dilakukan untuk mengetahui dan menunjang data-data lainya berdasarkan permintaan pasar, untuk mengetahui permintaan dari masyarakat sekitar mengenai tenant-tenant yang menjadi prioritas saat mall ini dibangun, namun hal ini tidak dapat dilakukan karena masa pandemic COVID-19.

Ada juga data yang diperoleh secara tidak langsung melalui media informasi. Media yang digunakan dapat berupa media cetak dan juga media elektronik. Serta data dari institusi yang terkait dengan objek studi. Instansi yang terkait dalam hal ini adalah pihak Kelurahan Pusaka Rakyat, sedangkan untuk media elektronik adalah Google Maps, Google Earth, Badan Pusat Statistik (BPS), Badan Pertanahan Nasional (BPN), Kabupaten Bekasi dalam angka, Kecamatan Tarumajaya dalam angka, Kelurahan Pusaka Rakyat dalam angka, Rencana Tata Ruang Wilayah Kabupaten Bekasi, Bank Indonesia.

\section{DISKUSI DAN HASIL}

Lokasi lahan pengembangan berada Jalan Harapan Indah Boulevard, Kelurahan Pusaka Rakyat, Kecamatan Tarumajaya, Kabupaten Bekasi. Berikut ini adalah profil dari lahan pengembangan :

Tabel 1. Profil Lahan Pengembangan

\begin{tabular}{ll}
\hline Lokasi & $\begin{array}{l}\text { Jalan Harapan Indah Boulevard, Kelurahan Pusaka Rakyat, Kecamatan } \\
\text { Tarumajaya, Kabupaten Bekasi. }\end{array}$ \\
\hline Luas & $59.092 \mathrm{~m}^{2}$ \\
\hline Bentuk & Beraturan \\
\hline Kondisi & Lahan Kosong yang siap dikembangkan \\
\hline Surat Kepemilikan & HGB \\
\hline Peruntukan & Komersial \\
\hline
\end{tabular}

Sumber : Olahan Penulis, 2020
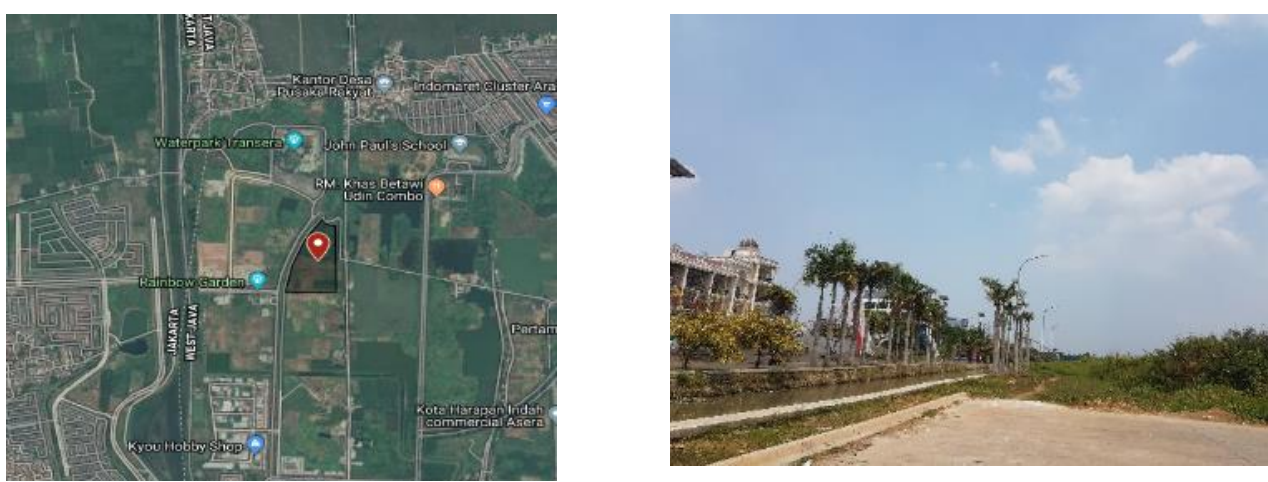

Gambar 1. Bentuk Lahan dan Kondisi di Dalam Lahan Sumber : Olahan Penulis dan Google Mymaps, 2019 
Aspek teknis yang diperhatikan adalah berdasarkan analisis lokasi yang dilakukan adalah aksesibilitas, proximity, karakteristik sekitar lahan, tren dan arah pengembangan, dan rencana kawasan yang akan melihat potensi serta kendala dari lahan pengembangan.

Tabel 2. Potensi dan Kendala Analisis Lokasi

\begin{tabular}{lll}
\hline Potensi & \multicolumn{1}{c}{ Kendala } & \multicolumn{1}{c}{ Analisa } \\
\hline Tapak berada di & - & Transportasi umum yang \\
kawasan CBD Kota & mencapai lahan objek & Lokasi sangat berpotensi \\
Harapan Indah yang & studi tidak langsung & sekali untuk berkembang \\
sangat berpotensi & mencapai objek studi & kawgan pesat dikarenakan di \\
menjadi area & melainkan masih & banyak aktifitas, dan juga \\
komersial & berjarak sekitar 1 & banyak proyek yang sedang \\
& kilometer lagi dari objek & berjalan di sekitar tapak \\
& studi &
\end{tabular}

- Memiliki aksesibilitas yang baik dari Jakarta maupun Kota Bekasi
- $\quad$ Arah utara tapak yang masih belum dilakukan pengembangan
- Lokasi sangat strategis berada di pusat Kota Harapan Indah sehingga mudah dicapai dari berbagai arah

\begin{tabular}{llll}
\hline - Terdapat beragam & Dalam radius 5kilo & Aksesibilitas cukup baik, \\
fasilitas penunjang yang & & terdapat banyaknya & kondisi jalan baik dengan \\
cukup lengkap di sekitar & industry disekitar lokasi, \\
lokasi objek studi & yang menyebabkan & RoW yang direncanakan \\
& polusi/limbah & mencapai 40 meter.
\end{tabular}

- Kawasan sudah sangat berkembang sudah terdapat banyak sekali hunian disekitar, ditambah lagi dengan perumahan Jakarta Garden City yang berada sangat dekat dengan lokasi

\section{- Adanya kompetitor sejenis dengan jarak +- 3 kilometer}

- Berada diantara kawasan hunian yang sudah terhuni bahkan berada juga di dekat area hunian kompetitor yang bahkan berpotensi juga untuk jadi target pasar

- Merupakan daerah yang berkembang pada awal

- Pusat kegiatan terdekat

2010 an. Menyebabkan berjarak sekitar 3

Kota Harapan Indah menjadi daerah yang kilometer, namun selain itu pusat kegiatan terdekat sedang berkembang lainya berjarak 10 kilometer

- Kota Harapan Indah berada di ujung wilayah Kabupaten Bekasi dan Jakarta merupakan daerah pertemuan sekaligus perbatasan

Sumber : Olahan Penulis, 2020

Aspek teknis yang diperhatikan adalah bedasarkan analisis tapak yang dilakukan adalah karakteristik tapak, pencapaian dan sirkulasi, aktifitas lingkungan, nilai lahan, dan legalitas yang akan melihat potensi serta kendala dari lahan pengembangan. 


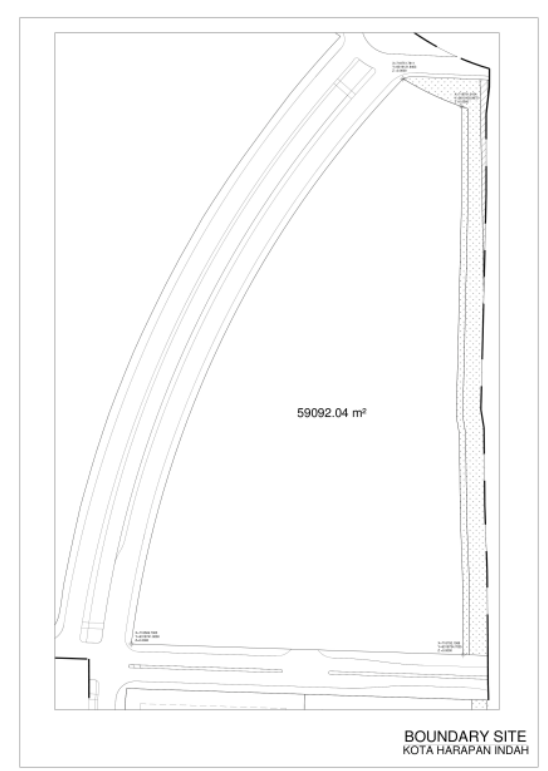

Gambar 2. Batas Lahan

Sumber : PT Hasana Damai Putra, 2019

Tabel 3. Potensi dan Kendala Analisis Tapak

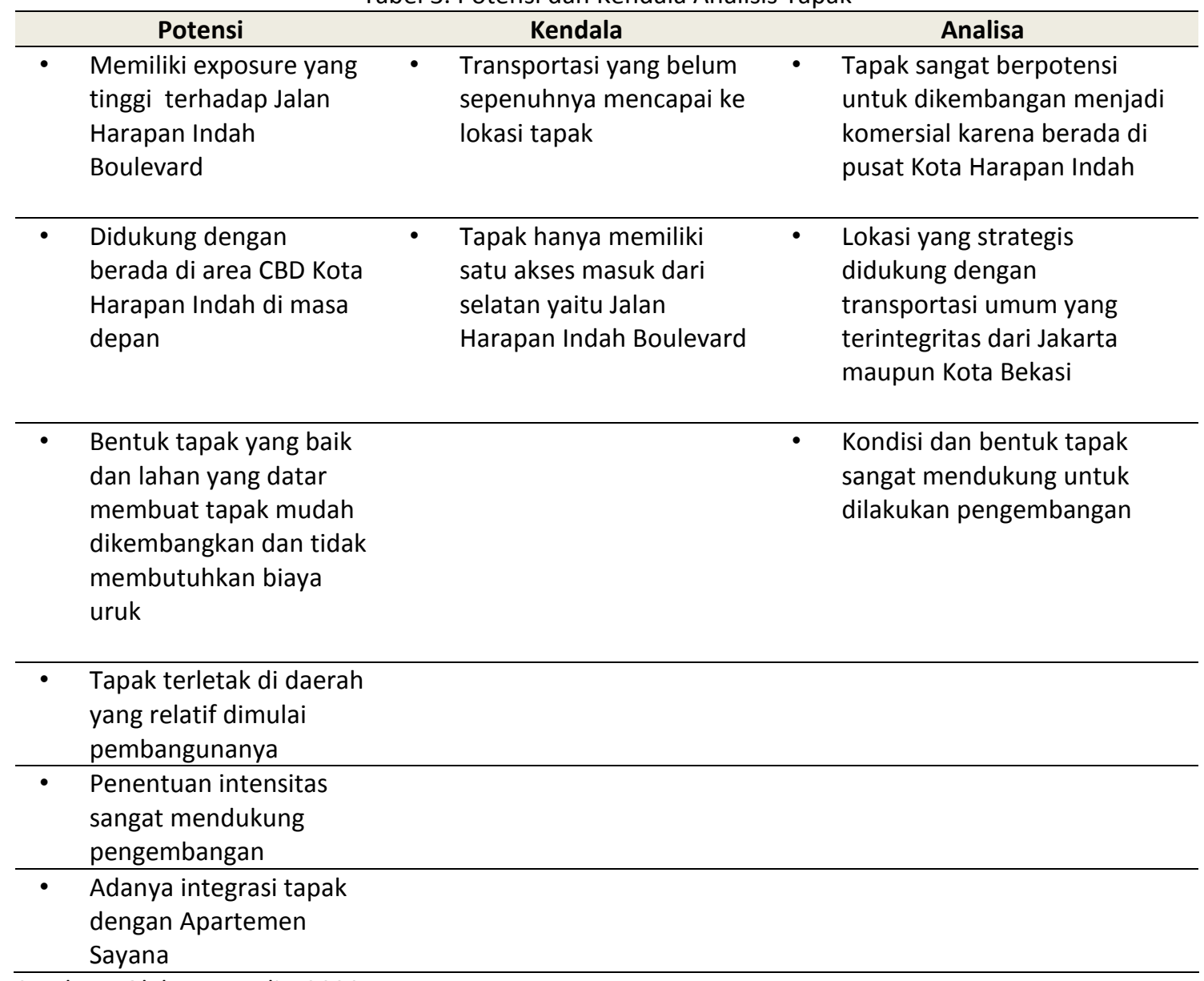

Sumber : Olahan Penulis, 2020

Untuk dapat menentukan Market Positioning, Competitive level, dan Market Share caranya dengan menentukan nilai terlebih dahulu dari faktor yang mempengaruhi pengembangan 
Shopping Center terhadap masing-masing kompetitor dan objek studi itu sendiri ditambah dengan harga sewa $/ \mathrm{m}^{2}$ unit Shopping Center. Berikut adalah tabel yang menunjukkan penilaian terhadap kompetitor dan lahan objek.

Tabel 4. Skoring Kompetitor

\begin{tabular}{|c|c|c|c|c|c|c|c|c|c|}
\hline \multirow[t]{2}{*}{$\begin{array}{l}\mathrm{N} \\
\mathrm{O}\end{array}$} & \multirow[t]{2}{*}{ Mall } & $\begin{array}{l}\text { Loka } \\
\text { si }\end{array}$ & $\begin{array}{l}\text { Aksesibli } \\
\text { tas Jalan }\end{array}$ & $\begin{array}{c}\text { Exposu } \\
\text { re/ } \\
\text { Visibilit } \\
y\end{array}$ & $\begin{array}{l}\text { Tenan } \\
\text { cy Mix }\end{array}$ & $\begin{array}{l}\text { Costu } \\
\text { mer } \\
\text { Mix }\end{array}$ & $\begin{array}{c}\text { Tipe } \\
\text { Bangunan }\end{array}$ & $\begin{array}{c}\text { Skori } \\
\text { ng }\end{array}$ & \multirow[t]{2}{*}{$\begin{array}{c}\text { Base Rent } \\
\quad(\mathrm{Rp})\end{array}$} \\
\hline & & $25 \%$ & $25 \%$ & $10 \%$ & $15 \%$ & $15 \%$ & $10 \%$ & $100 \%$ & \\
\hline 1 & $\begin{array}{l}\text { Metropolitan Mall } \\
\text { Bekasi }\end{array}$ & 3 & 5 & 3 & 3 & 3 & 3 & 3.5 & 450,000 \\
\hline 2 & $\begin{array}{l}\text { Grand } \\
\text { Metropolitan }\end{array}$ & 3 & 3 & 1 & 5 & 3 & 1 & 2.9 & 380,000 \\
\hline 3 & $\begin{array}{l}\text { Summarecon Mall } \\
\text { Bekasi }\end{array}$ & 3 & 3 & 5 & 5 & 5 & 3 & 3.8 & 475,000 \\
\hline 4 & AEON Mall JGC & 5 & 3 & 5 & 5 & 5 & 1 & 4.1 & 650,000 \\
\hline 5 & SUBJECT SITE & 3 & 3 & 5 & 5 & 5 & 1 & 3.6 & 500.000 \\
\hline
\end{tabular}

Sumber : Olahan Penulis, 2020

Tabel 5. Market Share dan Competitive Level

\begin{tabular}{llcc}
\hline No & Nama Mall & Market Share & Competitive Level \\
\hline 1 & Metropolitan Mal Bekasi & $20 \%$ & $85 \%$ \\
\hline 2 & Grand Metropolitan & $16 \%$ & $71 \%$ \\
\hline 3 & Summarecon Mall Bekasi & $21 \%$ & $93 \%$ \\
\hline 4 & AEON Mall JGC & $23 \%$ & $100 \%$ \\
\hline 5 & SUBJECT SITE & $20 \%$ & $88 \%$ \\
\hline
\end{tabular}

Sumber : Olahan Penulis, 2020

Tabel 6. Demand Absorbtion

\begin{tabular}{lr}
\hline DEMAND ABSORPTION & \\
\hline Mulai Pengembangan Mall & 2021 \\
\hline Mulai Beroperasi & 2023 \\
\hline Total Household in catchment area & 744472 \\
\hline Middle Upper Income Groups & $35 \%$ \\
\hline Target Market & 260565.2 \\
\hline Market Share & $20.00 \%$ \\
\hline Total Captured Shopper & 52113 \\
\hline \%of Occasional Shoppers & $25 \%$ \\
\hline Total Shoppers & 65141 \\
\hline Estimated Household Monthly Disposable Income & $3,500,000.00$ \\
\hline Persentase berbelanja di Mall Proyek & $30 \%$ \\
\hline Total Belanja Potensial Konsumen & $\mathrm{Rp} 68,398,365,000$ \\
\hline Sales Turnover Spent on Rent & $20 \%$ \\
\hline Total Potential Captured Expenditure & $\mathrm{Rp} 13,679,673,000$ \\
\hline Average Rent & 300000 \\
\hline Total Estimated Demanded Space NLA & 45599 \\
\hline GFA & 75998.18 \\
\hline
\end{tabular}

Sumber : Olahan Penulis, 2020 
Demand absorbtion menunjukan total shopping mall yang dapat diserap di sekitar lahan objek studi adalah NLA $45.599 \mathrm{~m}^{2}$ dan GFA sebesar $75.998 \mathrm{~m}^{2}$, dengan NLA sebesar $60 \%$ dari luas bangunan maka akan dibangun dan dibagi per lantai sebagai berikut.

Tabel 7. Rencana Pengembangan Objek Studi

\begin{tabular}{crrr}
\hline Lantai & Luas bangunan $\left(\mathrm{m}^{2}\right)$ & NLA $\left(\mathrm{m}^{2}\right)$ & Persentase \\
\hline GF & 17100 & 10260 & $22.5 \%$ \\
\hline $1 F$ & 17100 & 10260 & $22.5 \%$ \\
\hline $2 \mathrm{~F}$ & 17100 & 10260 & $22.5 \%$ \\
\hline $3 \mathrm{~F}$ & 17100 & 10260 & $22.5 \%$ \\
\hline 4F & 7600 & 4560 & $10 \%$ \\
\hline Total Luas & 75998 & 45599 & $100 \%$ \\
\hline
\end{tabular}

Sumber : Olahan Penulis, 2020

Tabel 8. Harga Sewa Tenant per Mall Beroperasi

\begin{tabular}{llll}
\hline Lantai & Persentase NLA & Rata-Rata Harga Sewa \\
\hline GF & $22.5 \%$ & IDR & $337,777.78$ \\
\hline $1 \mathrm{~F}$ & $22.5 \%$ & IDR & $333,333.33$ \\
\hline $2 \mathrm{~F}$ & $22.5 \%$ & IDR & $266,666.67$ \\
\hline $3 \mathrm{~F}$ & $22.5 \%$ & IDR & $216,666.67$ \\
\hline $4 \mathrm{~F}$ & $10.0 \%$ & IDR & $150,000.00$ \\
\hline Asumsi Kenaikan Sewa per Tahun & Rata-Rata 2020 & IDR & $274,750.00$ \\
\hline $3 \%$ & Rata-Rata 2021 & IDR & $282,992.50$ \\
\hline & Rata-Rata 2022 & IDR & $291,482.28$ \\
\hline & Rata-Rata 2023 & IDR & $300,226.74$ \\
\hline
\end{tabular}

Sumber : Olahan Penulis, 2020

Karena mall akan beroperasi pada tahun 2023 maka harga sewa akan mengikuti per tahun 2023.

Tabel 9. Cash In dan Cash Out

\begin{tabular}{ccc}
\hline Skema Penjualan & Total Cash In & Total Cash Out \\
\hline Pesimis & Rp 2,564,354,839,514 & Rp 1.018.167.448.896 \\
\hline Moderate & Rp 2,974,161,388,028 & Rp 1.018.167.448.896 \\
\hline Optimis & Rp 2,974,161,388,028 & Rp 1.018.167.448.896 \\
\hline
\end{tabular}

Sumber : Olahan Penulis, 2020

Tabel 10. Cashflow Financing

\begin{tabular}{cl}
\hline Skema Penjualan & NPV, IRR, PI dan PP \\
\hline Pesimis & NPV $=$ Rp 247,523,470,645.55 \\
& IRR 15.02\% \\
& PP 11.04 \\
\hline Moderate & NPV $=$ Rp 406,084,206,431.47 \\
& IRR $16.75 \%$ \\
& PP 10.26 \\
\hline Optimis & NPV $=$ Rp. 438,651,858,437.60 \\
& IRR $17.21 \%$ \\
& PP 10.03 \\
\hline
\end{tabular}

Sumber : Olahan Penulis, 2020 
Cashflow yang dihitung adalah selama 15 tahun setelah mall beroperasi yaitu dari tahun 2021 hingga tahun 2037 setelah mall 15 tahun beroperasi, lalu dilanjutkan dengan menggunakan terminal value dikarenakan itu merupakan produk yang reccuring income.

\section{KESIMPULAN DAN SARAN}

\section{Kesimpulan}

Berdasarkan hasil analisis lokasi, tapak, pasar makro dan pasar mikro, konsep pengembangan, skenario pengembangan, dan analisis finansial dapat disimpulkan bahwa tapak memiliki potensi yang cukup baik untuk dikembangkan menjadi shopping mall karena aspek pendukung sudah terdapat pada tapak seperti aksesibilitas, luas tapak, exposure yang baik, lokasi yang strategis karena berada di bakal central business district dengan demand yang cukup tinggi terlihat dari karakteristik lokasi sekitar yaitu perumahan kelas menengah menengah atas. Berikut ini merupakan spesifikasi pengembangan properti shopping mall : Shopping mall 5 (lima) lantai dengan skala pelayanan regional dengan gross floor area $75.998 \mathrm{~m}^{2}$ dan net leasable area 45.599 $\mathrm{m}^{2}$. maka didapatkan IRR untuk shopping mall adalah $16.75 \%$ atau $4.75 \%$ lebih tinggi dari suku bunga $12 \%$, juga NPV sebesar Rp 406,084,206,431.47 Pengembalian modal sudah tercapai pada tahun ke-10 Q1, namun karena pembayaranya per tahun maka payback pada tahun ke 11 Berdasarkan IRR, PP dan NPV dapat dikatakan bahwa objek studi dikatakan layak untuk dikembangkan.

\section{Saran}

Penelitian ini dilakukan pada masa kondisi pandemi COVID-19, harga sewa retail saat ini mendapatkan potongan harga, dan setelah berdiskusi dengan dosen pembimbing diputuskan bahwa tidak mengikutsertakan faktor COVID-19. Oleh karena itu dibutuhkan penelitian lanjutan.

\section{REFERENSI}

Camp, R. (2006). Benchmarking:The Search for industry Best Practices That Lead to Superior Performance :1st Edition .

Damodaran, A. (2006). Damodaran on Valuation: Security Analysis for Investment and Mun. New Jersey.

Griffin, R. \&. (2006). Bisnis. Jakarta: Erlangga.

Kotler, P. (2003). Manajemen Pemasaran. Edisi kesebelas. Jakarta: PT Gramedia Pustaka Utama.

Kyle. (2002). Property Management, Real Estate Education.

Maitland. (1987). Shopping malls Planning and Design, London Costruction Press.

Multiyaningsih. (2008). Metode Penelitian Terapan Bidang Pendidikan. Bandung: Rosdakarya.

Rangkuti, F. (2010). Analisis SWOT Teknik Membedah Kasus Bisnis. Jakarta: PT Gramedia Pustaka Utama.

Sumastuti. (2006). In Sumastuti, Keunggulan NPV Sebagai Alat Analisis Uji Kelayakan Investasi Dan Penerapannya. Jurnal Manajemen (7) (pp. 119-140). Jakarta: Erlangga.

Yuliati, S. (2014). Studi Kelayakan Bisnis. Jakarta. 
